\title{
The need for improvement of External Audit Reports of banks (The case of banks in Albania which mainly belong to EU Banks)
}

\author{
VALBONA CINAJ $^{1}$, MANUELA MEÇE ${ }^{2}$, ARTUR RIBAJ $^{3}$, ILDA KADRIMI $^{4}$ \\ ${ }^{1}$ University of Tirana, ALBANIA \\ ${ }^{2}$ Faculty of Applied and Economic Sciences, Albanian University, ALBANIA \\ ${ }^{3}$ Faculty of Economics, Tirana University, ALBANIA \\ ${ }^{4}$ Faculty of Applied and Economic Sciences, Albanian University, ALBANIA
}

\begin{abstract}
The financial crisis of 2008 highlighted weaknesses in risk management, control and governance of banks, auditing, and financial supervision. This led to increased consideration of the respective roles and interactions of banking supervisors with external and internal auditors, who are key contributors to market discipline. Auditors ensure that financial information is transparent and reliable while supervisors provide confidence in financial systems. On the other hand, auditors enable market players to make decisions based on this information and contribute to financial stability. In 2014, the Basel Committee on Banking Supervision considered the interaction between supervisors and external auditors by enabling their relationships to improve the quality of banks' audits, financial statements, and effective supervision of the banking system. Since 2015, the Bank of Albania has adopted its regulatory framework almost fully compliant with these principles. This paper analyses the typology of issues identified in the external audit reports of the 10 largest banks in Albania for 2018 and needs for their improvement.
\end{abstract}

Keywords: -Banks, Auditing, Government Policy and Regulation. JEL Code: G21; M42; G28.

Received: December 23, 2019. Revised: June 8, 2020, Re-revised: June 12, 2020. Accepted: June 16,

2020. Published: June 17, 2020

\section{Introduction}

The recent financial crisis not only revealed several management flaws, control and risks failures in the governance of banks, but also highlighted the need to improve the quality of banks' external audits. External auditors of banks can play an important role in contributing to financial stability when they provide quality banking audits that promote market confidence in banks' financial statements. Nowadays banking audit is a profession that requires specialized standards and technical knowledge. Preparing the auditor requires a long, intensive academic pursue and practical steps. The breadth and depth of the knowledge required to perform the audit is constantly expanding. External auditors deal not only with the financial controls of the organization but with all controls for the good governance of the bank. They continuously evaluate and test the effectiveness of controls designed to assist the bank in achieving the objectives and goals set by the risk appetite of their boards of directors which are built in Albania somehow in accordance with the Corporate Governance principals ensuring their independence with at least $2 / 3$ of the members of Banks' Board of Directors. External auditors also assist the members of the board of directors and audit committees in carrying out their duties and responsibilities by providing them with analysis, findings, and evaluations.

\section{Methodology}

Descriptive research: According to Robson, the purpose of descriptive research is to "describe an accurate profile of persons, events, or 
situations". Descriptive studies help you gather data and respond to research objectives when you have a clear view of the concepts you want to study [19]. For the purpose of this study, 10 commercial banks operating in Albania were interviewed and their responses analyzed based on external audit reports for the fiscal year 2018 . Interpretive analysis is used to realize the purpose and objectives of the study. Existing literature, legal framework, conclusions from various well-known authors in this sector is analyzed. Also referring to the specific publications, reports of external auditors and to the internal control systems of commercial banks, the authors of this article will provide an overview of functioning of Albanian banking through the findings and recommendations of the latter.

\section{Literature Review}

\subsection{The main object of External Audit}

According to international auditing principles, external audit for banks is required to: provide consistent audit information to all stakeholders; increase efficiency and effectiveness in audits and evaluations carried out; audit planning based on "Real Time Information" on Risk Management Models and Trends; eliminate gaps created by misstatements in statements; ensure significant improvements in risk management and effective organization of bank work; produce automated reporting; assist systems to estimate based on parameters with the qualitative dimension of risk analysis. In addition to the importance of the audit process in general, the Bank's External Auditors themselves have a key role to play in promoting a qualitative banking audit through effectiveness of their external audit responsibilities. Building effective relationships between bank administrators (board members and audit committee) with external auditors can support the effectiveness of bank supervision. For example, auditing a bank's financial statements can help identify weaknesses of internal controls specifically for financial reporting, that has the main purpose to summarize supervisory efforts and contribute to a safe and sound banking system. The World Bank survey of 2015 confirms that enhancing the relationship between supervisors and external auditors is a strategic imperative for both audit quality and the effective supervision of banks in the European and Central Asia [20]. Also, BASEL guidelines promote and establish communication channels between the bank's supervisor and external auditors [1], [2]. External audit in the Albanian banking system should operate in accordance with the applicable legal and regulatory framework, which is based on Albanian legislation framework and international audit standards [17]. While external audit contributes as an outside watchdog, ensuring transparency for an organization's financial statements not only for the board of directors and shareholders, but also delivers valuable information to the supervisory authorities which receive annual reports from external auditors and the audit report from internal control system [13]. The supervisory agencies may ask to get other detailed reports for oversight and the front line (business) and may act on any items of concern from any party. Also, external auditors can be an outside check on internal governance functions, including possible observations on the effective implementation of all three lines of defense model. The main object of External Audit is: Testing of historical financial transactions, examination of financial statements and certification of balance sheet on annual economic and financial activity. External Auditor, both for the public and private sectors, directs his work on auditing the financial and accounting system, aiming to provide sufficient evidence to determine whether the financial statements have been prepared: compliance with relevant legislation and accounting standards. In recent years, European banks subject to European Central Bank supervision have faced the need to adjust their risk management models to make sure they are deriving appropriate value from their internal control functions [11]. Despite the fact that Internal Audit (IA) plays a fundamental role for the added value that banking systems transmit to consumers, External Audit and strong cooperation between them are so much needed. Regulatory developments, stakeholders, expectations, business growth, and operational risks have contributed to a greater complexity of IA functions [8]. Also, there are some other demands by customers for banks' 
internal auditors in Albania asking a better efficiency of banks sources, because of poor access to symmetrical financial information, and trust-conscious choice avoid having a formal banking relationship [14]. However, bank shareholders and supervisors should keep in mind that: - The external auditor is an external contractor and not an employee of the organization as the internal auditor is; - The external auditor is required to give his/her opinion on whether the accounts illustrate a real image, even when confronted with the internal audit conclusion on the appropriateness and effectiveness of risk management and internal control systems, many of which fall outside the main accounting system according to [11]; • External audit can be far beyond the engagement and objectives of internal audit as External Audit services are perceived as being contracted only by the banks' executives as a legal requirement and not a necessity for bank activity.

\subsection{The role of audit in identifying management problems in banks}

The Audit process is made responsible for "collecting and interpreting reports of selected business facts" enabling executives to keep track of significant business developments, activities and outcomes from diverse and voluminous transactions according to [12]. Meanwhile, Rule 203 of the Code of Professional Conduct explains that in unusual situations, breaching a generally accepted accounting principle is not necessarily accompanied with a negative opinion for the principle in question. However, to justify an unqualified opinion, the auditor must state and explain, in a particular paragraph or section of the audit report, that adhering to the principle would produce a misleading result in that situation. Banks in Albania in respect of legal and regulatory framework are applying either local standards or international accounting standards [17]. The last one is important especially for banks that belong to European Banks and are listed in EU stock market or in any other international stock market. Doing so, all these banks face extra cost for converting their financial statement from local format to internationally accepted format [3].
Under certain circumstances, the External Auditor may wish to point out specific issues regarding the financial statements, although he or she intends to express an unqualified opinion on the statements. Normally, these explanations should be included in a separate paragraph in the report [6]. Examples of disclosures that the auditor may report as an emphasis of an issue may include the following: - Existence of related party transactions; $\bullet$ Significant events that occur after the balance sheet date; etc.; • but may also include a lack of competition among banks. Competition in the Albanian banking system is at a relatively low level and that no best practices are being applied by any other South Eastern European bank countries either [15].

It is essential that auditors and readers of audit reports understand the circumstances when a report is unqualified or inadequate. In studying audit reports that are part of an unqualified report, there are three closely related topics: conditions that require a departure from an unqualified opinion, types of opinions other than unqualified, and materiality. When the auditor has not accumulated enough appropriate evidence to conclude that the financial statements have been disclosed in accordance with appropriate financial reporting, there is a limitation of scope. There are two main causes of scope limitations: limitations imposed by the client and those caused by circumstances beyond the client or the auditor control. An example of customer restriction is the refusal to allow the auditor to confirm material receivables or physically examine the inventory [9].

\subsection{Crucial aspects in writing an audit report}

Report's Executive Summary. A two - or three -page summary may be attached to the front of the report or issued as a separate document. It provides a concise summary of the key objectives, conclusions and steps management must take. This indicates that managers are busy and want to get a brief summary of any material issues that may result from an audit [11].

Report's Recommendations. Auditors can make a vast array of recommendations, and these must be structured to maximize impact. 
There should be some steps that enable good management, and these should be detailed in the opening section of the recommendations. Recommendations should be designed to put management in a position to implement the various recommendations. This will appear in every executive summary and should not consist of more than two or three articles to discuss. The remaining recommendations should be followed as a matter of priority. A useful approach is to document a set of recommendations for each key part of the report and then repeat as the final part of the executive summary (cross reference to the main report). Recommendations should be presented to create maximum impact. There are many executives who are primarily interested in what is being recommended and why according to [11].

Review of External Audit Report. The audit work must be reviewed before a report can be published and this should occur at two levels. First, there should be a supervisory review of the underlying working documents where all audits and findings should be supported by a welldocumented audit work. The second level focuses on the audit report and the way the work, conclusions and recommendations are expressed. The review should look at the quality and quantity of work. If the work is reviewed as the draft report progresses, it will not be deferred pending the review of the audit managers [5].

The review of the report may be focused on: Structure - Where are the findings based? $\bullet$ The tone of the report - How they are expressed? Shortcomings - How clear is the terminology used? - Spelling and grammar to be clear for a symmetric information [11].

The opinions are categorized as: In an unqualified opinion, the auditor states that the financial statements fairly present all material aspects, financial position, results of operations and cash flows of an entity in accordance with IAS (IFRS). While not affecting an unqualified opinion, certain circumstances may require the addition of an explanatory paragraph to the audit report [6]; In a qualified opinion, the auditor states that "in addition to the effects of qualification-related matters, the financial statements present, in all material respects, the financial position, results of operations and cash flows of the entity in accordance with IAS (IFRS). In an adverse opinion, the auditor states that the financial statements do not accurately represent the entity's financial position, results of operations and cash flows in accordance with GAAP. While not denying unqualified opinion, certain circumstances may require an additional explanatory paragraph or at least explanatory language to the standard report.

\section{Analysis}

\subsection{Legal and regulatory framework for External Audit of banks in Albania}

Banks in Albania are subject to External Audit, which is a legal and regulatory obligation of the Bank of Albania under Law no. 9662, dated 18.12.2006, "On Banks in the Republic of Albania", as amended, as well as in the Regulation on Internal Audit System, there are some legal requirements regarding the audit. Other related regulations and audit function as part of the control system are cited throughout their articles. The regulatory framework for the internal control system in Albania is almost completely in line with BASEL's Corporate Governance principles. Monitoring the implementation of the legal and regulatory framework is one of the tasks of the External Audit, alongside the first two lines of protection in commercial banks in Albania, their Internal Audit, and the Bank of Albania which has applied the 3LoD model (3 Model Defense Lines).

In Article 38 of Law no. 9662, regarding the Audit Committee, consists of three members who are appointed by the shareholders assembly for a four-year term, with the right to be reelected. Audit committee members are individuals with at least 3 years of experience in the field of accounting and/or auditing. The Audit Committee has the following duties: a) to oversee and supervise the implementation of the bank's accounting and internal control procedures, including the procedures established by the Bank of Albania; b) to audit bank 
accounts and related records; c) review internal control reports and monitor the implementing of conclusions drawn from these reports; d) proposes the authorized accounting expert and conducts the communication between him and the internal audit of the bank; e) assesses the bank's financial situation based on the report of the authorized accounting expert; f) checks the compliance of the bank's activity with the laws and bylaws and notifies the bank's board of directors of its conclusions; g) give opinion to the bank's board of directors on all problems required by the bank; $h$ ) approves the financial reports and statements prepared by the bank for the purpose of their publication. The audit committee reports to the board of directors and assists the latter in bank decision-making and oversight.

In Article 45 of Law no. 9662, regarding the Internal Control System, the Bank or the Branch of a foreign Bank organizes the internal control system, in order to monitor the implementation of internal policies and procedures, to evaluate the effectiveness of banking activity and to monitor compliance with legal acts and subsidiary. The purpose of internal control is to identify the exposure of the bank or branch of a foreign bank to the types of risks, measures, manage and monitor their level. According to Ribaj, Ilollari, Scalera, (2019) even after 10 years since the last financial crisis, people are still afraid to deposit all their savings in banks and deposit withdrawals are considered to be the most "commonplace" activity. The system of internal control of the bank or branch of a foreign bank consists of a set of procedures, rules and structures, which exist within it. Internal control activity is an integral part of the day-to-day operation of the bank or branch of the foreign bank and includes control within each of its organizational units, physical controls over assets and information, compliance assessments, control of the vetting and reconciliation system. financial information, as well as periodic reviews of the effectiveness of previous controls.

In Article 49 of Law no. 9662, concerning the Audit of an Authorized Accounting Expert. It is approved by the Bank of Albania, checks and evaluates the compliance of the financial reports of the bank or branch of a foreign bank with the law "On accounting and financial statements" and international accounting standards. The authorized auditor audits and evaluates: the profit and loss account (income and expense statement); the balance sheet; report on changes in equity; cash-flow statement; implementation of policies for deleting balance sheet items; consolidated reports; internal control function; accounting records; information systems; accuracy and completeness of reports submitted to the Bank of Albania; adequacy of accounting procedures and enforcement of regulations; notes accompanying financial reports. Authorized Accounting Experts verify whether the accounting and financial records are properly maintained based on the methodology provided by the Bank of Albania and IFRS. They prepare an annual report including the internal audit opinions on the complete and accurate presentation of the financial position of the bank or branch of a foreign bank, based on the financial statements prepared by the bank or branch of the foreign bank in accordance with the law "On Accounting and Financial Statements" and international accounting standards. They also, review the adequacy of internal control practices and procedures and makes appropriate recommendations.

Also, in Article 51 of Law no. 9662, the Bank of Albania has the right to request re-auditing by another accounting expert in cases where the authorized auditor of the bank or branch of a foreign bank has performed an audit and has submitted a report which is not in compliance with the requirements of this law and national and international auditing standards and does not express the real state of the bank. In the cases provided for in paragraph 1 of this Article, the Bank of Albania shall be entitled to exclude the accounting expert for a period of 5 years from conducting audits of banks or branches of foreign

banks.

\subsection{Analysis of External Audit Reports on Banking Activity for 2018}

From all 10 external audit reports of commercial banks analyzed, the main findings encountered 
for most of the banks obtained in this study were:

- The audit groups set up under the audit plans in the banking sector should consist of at least three auditors, 2 members and 1 team leader. Out of 10 external audit reports that have been reviewed, this principle is not met by a significant part of commercial banks and this also results in the malfunction of the audit system in these banks.

- From the data analysis $80 \%$ of commercial banks are established and operate in compliance with the legal and sub-legal acts, thus fulfilling this criterion.

- Consolidated data shows that $81 \%$ of commercial banks have internal audit cards approved and that meet the criteria for being subject to external audit.

- The role of internal audit along with external audit is to assist the audited unit in achieving its objectives which should be in line with bank's objective. Internal audit objectives should always be in line with the objectives of the banking unit. The data analysis shows that $82 \%$ of these units have their objectives in line with the objectives of the banking group they represent.

- It is the task of the external auditor who in the planning process should identify and evaluate the risks of certain bank units and compare the information with that obtained from the internal audit and take in consideration the bank risk assessment. Based on this finding and evaluation, the external auditors need to identify the high-risk bank's units and include it in the annual audit plan. From the analysis, resulted that $54 \%$ of the external auditors base their audit plan on internal audit reports and risk assessment of the bank or banking group.

- The Internal Audit Manual has a clear procedure for reporting audit engagement. It is noted that $77 \%$ of the banks considered prepare and submit the audit report in accordance with the requirements of the Internal Audit Manual, which is later compared to the results obtained from the external audit report.
- The filing of an audit engagement should be accurately completed with all working papers such as the engagement program, justification of findings, draft reports, audited party's remarks, final report, etc. The consolidated data shows that $89 \%$ of commercial banks manage to submit a complete file of working documents.

- Upon completion of audit files as defined by Internal Audit Manual, they are archived according to the relevant legal acts. It is noted that $62 \%$ of banks units archive permanent files according to the applicable legal acts.

- Almost all the external audit reports of the banks that were taken into consideration were carried out by the largest audit companies operating in Albania which improves the credibility to the audit report and bank performance.

- External audit of all the banks included in this research is performed on the financial statements (AFS) of the bank. All of External Audit reports on the bank's financial position, whether executed by KPMG, E\&Y, PWC, DELOITTE or GRANT THORTON, are consistent in their implementation. All note the bank's FS policy and make a summary of the bank's financial situation, without departing from the framework.

- The most essential part of an audit report is the recommendations given to stakeholders (executives and senior management). Managers and senior management of banking groups need to receive more efficient recommendations regarding the functioning of internal control systems and risk assessment for the proper organization of their branches. In this regard, auditors should make recommendations as applicable as possible and add value to the audited entity. What is evidenced in the External Audit reports that were taken into consideration state that almost all the reports provide a summary of how the FS of banks are presented, being very basic in making recommendations and without going into other areas of concern. are related to the good governance of the bank and the effectiveness in using the bank's resources. However, some of the recommendations given in the audit reports during 2018 can be identified as follows: 
- Recommendations related to the improvement of policy decision-making processes, procedures and strategy development, which assist commercial banks in setting annual, medium and long-term priorities and objectives as realistic as possible.

- Recommendations for improving certain specific aspects of the policy implementation processes, the internal and external legal and procedural framework governing the operation of commercial banks in the country.

- Recommendations for the improvement of organic structures, in view of the work effectiveness improvement.

- Recommendations for improvement of the elements of internal and external control system in order to achieve a more effective use of the the banking group funds y for the organization.

- Recommendations related to correcting actions on bank offenses during business hours, preventing abuse, violations and safeguarding assets owned by the bank or banking group.

- Recommendations related to the continuous professional development of staff in each bank.

In relation to the problems identified in this analysis, greater coordination of the banking group (parent bank) with its offspring in Albania is required to obtain the know-how and good governance of the internal audit service and coordination with the external audit, in full alignment with international standards.

From a thorough analysis of the situation and the impact of the External Audit, it is noted that a considerable number of commercial banks have been clear and concise in their statements and in the way they organize their work within their units. It is already known that the responsibility for implementing the recommendations rests with the top managers of the audited bodies themselves, but on the other hand the responsibility of external or internal audit is not limited to issuing these recommendations, but also to following them, as and the results of the work performed by the audit team depend on this aspect. If internal and external auditing play a passive role, which would consist merely of making confusing and inappropriate recommendations, then we would not have fulfilled the mission and strategic objectives of either bank branch. second tier, and more so the objectives of the banking group they represent. For this reason, the evaluation of the activity of auditors and internal or external auditing processes has a significant impact on the presentation of proposals for the measures to be taken and on the recommendations to be given regarding the subsequent activity of the banking unit.

Audit reports serve to ascertain positive findings or violations or deviations from internal procedures and external laws and regulations binding on the bank. Based on the available information and comparative basis (human resources and independent audit reports) it is observed that banks have only benefits from audit reports. The benefit is expressed in identifying problems, communicating and solving them. As well as not repeating these findings reflected in the future, serving as practical examples of what to avoid when practicing banking. Also, at the management level, the banking committee or group is given a clear picture of the procedures, concrete difficulties encountered by employees and in specific cases serve as a starting point for changing or adapting the latter.

\section{Conclusions}

1. The applicable legal and regulatory framework is in full compliance with the BASEL core principles of auditing and Corporate Governance.

2. Almost all the external audit reports of the banks included in the study were carried out by the International Audit companies operating in Albania. This ensures greater credibility to the bank's audit report and performance.

3. External audit of all the banks studied is performed only on the financial statements of the bank. All note the Bank's FS policy and provide a summary of the bank's financial situation, being considered as basic audit reports and having the same consistency in their implementation. They do not deal in depth with other areas related to the bank's good 
governance and effectiveness in using the bank's resources by its executives.

4. From a thorough analysis of the External Audit reports, it is noted that a significant proportion of commercial banks have been accurate in the financial statements they have made in their financial statements.

5. An analysis of the external audit reports obtained in the study indicates an increase in the quality of External Auditor's work compared to several years ago in terms of addressing the follow-up of recommendations left to be implemented by previous audit reports.

\section{Recommendations}

The recommendations refer to the analysis of external audit reports published online by commercial banks for the financial year 2018 are in themselves aimed at improving the relevant systems, reducing the level of risk in these systems and providing advice on solutions that enable growth. of sourcing performance. Recommended as follows:

1. The writing of the report by external auditors should be supported in concrete cases and more importantly weighed and dealt with rather than minor findings, as well as reports being submitted in a timely manner and not delayed as they lose coherence and effectiveness in addressing of their findings, etc.

2. Communicate the external audit report on a continuous basis not only once a year.

3. In ascertaining negative findings, specify in the recommendation procedures or exact specifications that have not been implemented in order to make the findings clearly understood, followed for improvement and not to repeat such findings in the future.

4. Leaving the time needed to address findings, and especially when they are findings with a high impact and probability of occurrence.

5. Senior executives should present to other levels of the bank hierarchy as effectively as possible the findings and recommendations received from the External Audit for achieving a more effective harmonization with those of the internal report.

6. Increase the efforts of external auditors to enhance the quality of their work in delivering concrete and applicable recommendations in the future.

7. External audit reports should have more reflections on the arguments for what should have been done on those identified as findings and recommendations given. Therefore, the external audit report should not include only the findings or just some general information about the financial statements.

8. Greater coordination of the Banking Groups with its daughters in Albania for the good governance of the internal audit service and the conduct of the external audit activity in order to fully align it with the implementation of international auditing standards.

\section{References:}

[1] Basel Committee. 2014. External audits of banks. Basel Committee on Banking Supervision. Retrieved from https://www.bis.org/publ/bcbs280.pdf

[2] Basel Committee on Banking Supervision. 2012. The internal audit function in banks. Basel Committee on Banking Supervision.

[3] Bank of Albania. 2017. Annual Report. 25 Years Bank of Albania.

[4] Cela H. 2004. "Towards application of new standards on accounting and auditing - Albanian challenge on implementing IAS/IFRSs and ISAs", OECD Report.

[5] Directive 2006/43/EC “On statutory audits of annual accounts and consolidated accounts", published by the European Commission in 2006.

[6] Hogan, C., Easley, M., E Lder, R., \& Arens, A. (2014). Auditing And Assurance Services An Integrated Approach 19 Edition. Boston: Pearson Education, Inc.

[7] Hayley Barker Hoogwerf (2019). ISA 315: Identifying And Assessing The Risks Of Material Misstatement Through Understanding The Entity And Its Environment. 
[8] KPMG (2018). Internal audit: Threading the needle. Ireland: KPMG International.

[9] Levine Siegel Qureshi \& Dauber (2008). The Complete Guide to Auditing Standards and Other Professional Sandards for Accountants.

[10] Matarneh, G. (2011). Factors determining the Internal Audit quality in banks-empirical evidence. International Research Journal of Finance and Economics, 73.

[11] Pickett (2005) ICT risk management in organizations: Case studies in Thai business.

[12] R K Mautz; Hussein A Sharaf. The philosophy of auditing. Sarasota, Fla.: American Accounting Association, [2006], (C)1964

[13] Ribaj, Artur and Bejtja, Merita, The Three Lines of Defense Model and Banks in Albania. QUANTITATIVE METHODS IN ECONOMICS. Volume XVII, No. 4, 2016, pp. $101-113$.

[14] Ribaj Artur, Meçe Manuela, Cinaj Valbona, Kadrimi Ilda (2020). WSEAS

Transactions on Business and Economics, DOI: 10.37394/23207.2020.17.16, Print ISSN: 1109-9526, E-ISSN: 2224-2899, Volume 17, 2020, Art. \#17, pp. 153163; Title: "Issues related to financial education of youth in a developing country (The case of Albanian Youth)",

[15] Ribaj Artur and Ilollari Orkida. (2019). WSEAS Transactions on Business and Economics, ISSN / E-ISSN: 1109-9526 / 2224-2899, Volume 16, 2019, Art. \#32, pp. 288-297; Title: “Asymmetric Information versus Banks' Costumer Trust, Albania case linked with SEE countries",

[16] Ribaj Artur, Ilollari Orkida, Scalera Francesco, (2019). WSEAS
Transactions on Business and Economics, Print ISSN: 1109-9526, EISSN: 2224-2899, Volume 16, 2019, Art. \#65, pp. 582-592; Title: "The unethical banking costs distrust of bank customers (Albania case as a model for SEE countries)"

[17] Ribaj, Artur, "Some Principles for Banks' Internal Control System in Albania" (2015). UBT International Conference. 115.

[18] Robson, C. (2002) Real world research: a resource for social scientists and practitioners. 2nd Edition. Oxford: Blackwell Publishers.

[19] Saunders, M., Lewis, P. and Thornhill, A. (2009). Research Methods for Business Students. 5 $^{\text {th }}$ Edition, Financial Times Prentice Hall.

[20] World Bank. 2015. Banking supervisors and external auditors : building a constructive relationship - supervisors insights (English). Washington, D.C. : World Bank Group.

\section{Creative Commons Attribution License 4.0 (Attribution 4.0 International, CC BY 4.0)}

This article is published under the terms of the Creative Commons Attribution License 4.0

https://creativecommons.org/licenses/by/ 4.0/deed.en_US 